\title{
Building aware and unaware consumers' trust towards family business: Evidence from Poland
}

\author{
Anna M. Nikodemska-Wołowik, Joanna Bednarz, Dagmara Wach, \\ Joseph P. Little, Mark A. Kubik
}

\begin{abstract}
A B S T R A C T
Objective: The objective of the article is to examine what attributes are assigned to family firms by consumers familiar and not familiar with family business in the context of trust-building and purchase intention.

Research Design \& Methods: A nationwide quantitative survey on a statistically representative random-cluster sample of 1091 consumers was conducted in 2018, based on the fundamentals of pre-survey qualitative research.
\end{abstract}

Findings: This study proves a low level of consumers' familiarity with family firms and indicates attributes assigned to family firms by two segments of buyers. The findings show for which segments the concept of endorsed identity could be influential in the purchasing process, and for which might it be a subordinate stimulus when compared to consumers' trust.

Implications \& Recommendations: Although a family firm's origin can serve as a cue to purchase, there is a challenge in educating the audience regarding the low level of consumers' knowledge of family businesses. A legal construct provided in this study may reinforce trust towards family firms accompanied with purchase.

Contribution \& Value Added: This study is based on a representative large sample of consumers, additionally divided into two portrayed segments. It proposes a process of how a family business identity may be endorsed. The proposed legal construct is a novelty in the market and has not been investigated in other scientific research.

\begin{tabular}{ll}
\hline Article type: & research article \\
Keywords: & family business; consumers; trust, purchase; endorsed identity \\
JEL codes: & D12, D22, O34
\end{tabular}

Received: 2 February $2020 \quad$ Revised: 4 June $2020 \quad$ Accepted: 19 June 2020

\section{Suggested citation:}

Nikodemska-Wołowik, A.M., Bednarz, J., Wach, D., Little, J.P., \& Kubik, M.A. (2020). Building aware and unaware consumers' trust towards family business: Evidence from Poland. Entrepreneurial Business and Economics Review, 8(3), 135-154. https://doi.org/10.15678/EBER.2020.080308 


\section{INTRODUCTION}

As family businesses (FBs) identity communication is gaining more attention for several years now (e.g. Nikodemska-Wolowik, 2006; Carrigan \& Buckley, 2008; Micelotta \& Raynard, 2011; Botero et al., 2013; Beck \& Kenning, 2015; Wolf, 2018; Lušňáková, Juríčková, Šajbidorová, \& Lenčéšová, 2019), the problem is worth investigating in specific aspects. One of them is individual consumers' perspective towards FB, with a special focus on trust for this type of entity.

Although the importance of trust is recognised in prior studies, the increased uncertainty in the business environment awoke major interest in the role of trust since the mid1990s (Ma \& Orgun, 2006; Bhati, 2015). Regarding the general decrease in trust towards businesses and institutions, which became evident since the financial crisis in 2008 , this study attempts to find a guarantee that can be accepted by buyers and help them make purchase decisions. In this context, FB is a convincing example. According to prior research, more buyers trust FBs over non-FBs (Eddleston et al., 2010; Beck \& Prügl, 2018; Lude \& Prügl, 2018; Rosina, 2018; Košičiarová, Kádeková, Holotová, Kubicová, \& Predanocyová, 2020). Paradoxically, only 51\% of consumers know which firms they buy from are FBs (Edelman Trust Barometer, 2017).

Moreover, firms in developed economies are more likely to brand themselves as family businesses than those in emerging economies (Hall \& Astrachan, 2015). This reveals a question: how do firms communicate the fact that they are a FB, especially in post-communist countries, who entered the European Union (EU) in the twenty-first century? A study on Polish firms may serve here as a case in point.

During the market transformation in Central and Eastern Europe, Poland was perceived as a leader of that process (Dąbrowska, 2011; Brunet-Tornton, 2017) and - as an EU member since 2004 - has been a development success, catching up with Europe's most advanced economies (Bogdan et al., 2015). Regarding some socio-economic conditions, Poland was "comparable with Mediterranean and even Anglo-Saxon countries" (Neesham \& Tache, 2010, p. 358). But contrary to these countries, Poland avoided recession during the 2008 financial crisis and became the eighth-largest economy in the EU and "Europe's new growth engine" (Bogdan et al., 2015). What is substantial from this research perspective, in Polish society with high family and group collectivism, family per se is the most treasured value, not only by elderly citizens but also by young Poles (Trends in consumers' behaviour in Poland, 2017; Zupan et al., 2017). Another rationale for investigating Polish buyers concerns the international milieu. Polish diaspora is one of the largest in the world, and native goods are targeted to meet this segment's needs across the UK, the USA, or Ireland (Burrell, 2016; de Wenden, 2016). Hence, Poland has evinced a profound interest of worldwide inquiries, focused on various economic analyses. However, the issues of consumer perceptions of FB expounded in this paper were mislaid.

In general, prior research demonstrates stronger consumer trust to $\mathrm{FB}$, alongside their poor knowledge of which firm is family owned. Astoundingly, some Polish non-FBs try to take advantage of positive FB perceptions and purport to be kin-owned enterprises, misleading their customers. Thus, the objectives of the article are:

- to examine what attributes are assigned to FB by consumers familiar and unfamiliar with FBs in the context of trust-building and purchase intention, 
- to detect if a direct and clear message of being a FB addressed to consumers would have potential.

This article attempts to fill the gap in prior studies regarding buyers' perceptions of FB, divided into two segments: aware and unaware consumers. The article contributes to extant literature by presenting a means how FB identity may be endorsed, i.e. enriched by an external, independent brand. The proposed legal construct is a novelty in the market and was not investigated in other scientific research to date. Moreover, according to recent profound overviews of scientific articles on the subject of FBs status and individual buyers, there is a lack of quantitative studies (Botero, 2013; Rosina, 2018; Wolf, 2018). The biggest sample noticed in the aforementioned surveys included 278 one-country respondents, which was not representative (Rosina, 2018). Dated January 2018, our survey covered a representative sample of 1091 buyers, being the first one on such a scale. It contributes to very rare quantitative studies on FBs, the majority of which is conceptual. Therefore, the present article seeks to answer the following research questions:

RQ1: What attributes are assigned to FB by aware and unaware consumers?

RQ2: What is the role of endorsed FB identity in trust-building?

RQ3: What is the potential of a proposed legal construct in encouraging buyers to purchase?

The paper is structured as follows. The next section covers the literature review, while section three presents the materials and methods applied in the research, section four exhibits the survey findings accompanied with a discussion, and section five concludes. Although in the existing literature there is no consensus on the codified definition of FB, this article adopted the concept of the European Commission (EC, 2009), which accentuates family ownership, decision-making rights, and involvement in governance.

\section{LITERATURE REVIEW}

Based on the recent literature review there are few articles that assumed consumers' perspective and directly assessed FBs' perceived trust (Beck \& Prügl 2018; Rosina, 2018; Wolf, 2018).

Research conducted among consumers shows that they associate trust with FB when compared to non-FBs (Orth \& Green, 2009; Eddleston et al., 2010; Binz et al., 2013; Binz Astrachan et al., 2014; Beck \& Kenning, 2015; Bednarz, et al., 2017; Lude \& Prügl, 2018). This means that trust could be perceived as a key element in the explanation of a FB's success (Cruz et al., 2010; Carrigan \& Buckley, 2008). Consumer perceptions of a firm result in trust towards this entity and its products (Vassilikopoulou et al., 2018) and vice-versa: trust becomes essential when discovering means that lead to positive buyers' perceptions of FBs (Wolf, 2018; Botero et al., 2013). Facing the lack of a dominant trust definition, scholars propose a list of terms that prevail in such interpretations (Castelfranchi \& Falcone, 2010; Hobbs \& Goddard, 2015; Kim \& Chao, 2019; Skvarciany, Jurevičienė, Iljins, \& Gaile-Sarkane, 2018). Besides, sometimes the concept of trust considers from the position of the "lack of trust" (Ners, 2017) or as one of the factors influencing the economic behaviour (Roudposhti, Nilashi, Mardani, Streimikiene, Samad, \& Ibrahim, 2018). Therefore, from our perspective, trust comprises reliability, longevity, business with a human face, 
high quality products, and commitment towards local communities. The current study also focuses on FB attributes which regarded Polish consumers' trust.

Regarding purchase intention, an extensive literature review by Bozic (2017) proves that trusting consumers are loyal, committed, and disposed to accept new products and company activities in the market. Thus, willingness to buy is the constituent of trust. As this inquiry conducted no market experiment, the reasoning applied to avowed purchases, another term for the intention to buy. Buyers associate better relational qualities with FBs compared to non-FB counterparts and consequently prefer goods offered by the former (Binz et al., 2013). Zanon et al. (2019) noticed the positive impact of consumer awareness of FBs on their actions, including purchase. FBs imprint their values and beliefs into the essence of their firms. Long-lasting family tradition, related to trust, can indicate high quality in the future. From this perspective, Lude and Prügl (2018) find that buyers indicate higher brand trust from the communication of a firm's family nature, resulting in stronger purchase intentions. Hence, this study intends to highlight references to family ownership as a trigger in communication between FBs and buyers.

Communication with consumers through an explicit identity, a properly imparted FB status may underpin trust as one of its strongest values (Mayo \& Fielder, 2006). FB identity is understood as a firm self-concept, embracing the idiosyncratic attributes resulting from kin-ownership (Nikodemska-Wolowik, 2006; Botero et al. 2013; Blombäck \& RamírezPasillas, 2012). Concerning market communication, explicit signals are more effective than indirect messages (Hartnett et al., 2016), furthermore, the possibilities of their effective usage increase significantly in terms of intensive ICT development (Bilan, Mishchuk, Samoliuk, \& Grishnova, 2019; Janšto, Polakovič, Hennyeyová, \& Slováková, 2019; Botos, Szilágyi, Felföldi, \& Tóth, 2020; ). According to Zanon et al. (2019), a large number of FBs worldwide explicitly communicate their family status to stakeholders, but there are countries like Poland, in which consumers are not always able to identify themselves as familyowned. This low level of awareness was confirmed by Schwass and Glemser (2016) who suggest that an FB must be positioned in audience's perceptual space. Moreover, a plain communication strategy to capitalize on the FB status is widely recommended (Wolf, 2018; Rosina, 2018). It can create appropriate market advantages for social enterprises, which are kin-owned to a great extend and at the same time they are especially important for the labour market problems mitigation (Bilan, Mishchuk, \& Pylypchuk, 2017). Buyers build their trust for a brand on their positive experiences alongside communication activities (Brunner et al., 2019), including available information concerning employer brand (Urbancová \&Hudáková, 2017). Correspondingly, Botero et al. (2019) advise to explore how the audience perceives FB in regard to the type of a branding strategy used by FB. The authors present three concepts yet do not deliberate the option proposed in the current study. Therefore, this article aims to highlight the importance of designing a clear yet credible message sent to buyers. Prior studies confirm that information from a firm is less credible than the information from an independent source (Brunner et al. 2018; Dutta \& Pullig, 2011). Nonetheless, scholars claim that the family firm category can be defined as a brand of its own (Botero et al., 2013; Wolf, 2018). To reconcile both perspectives, this article proposes a category of an endorsed mark, similar to an 'umbrella brand,' protected by law. In Polish legislation, comparable to the EU and international regulations, such a 
brand is registered by an organization like an association of producers, which enables buyers to distinguish goods or services certified by the proprietor of the brand; in legal terminology: collective certification trademark. Contrary to an individual brand, the owner cannot use the brand him/herself (Regulation (EU) 2017/1001, 2017). Concurrently, the brand is registered for the purpose of licensing it to its members as a sign of membership in that particular organization. According to the signalling theory presented below, the brand sends a message to the buyers that the firm belongs to a certain association and owns the rights to use this mark, which help to shape consumer trust. However, there were only a few scientific papers related to this matter, and most concerned food products. Norberg (2000) argues that these brands can assist consumers in their buying decision.

To achieve the aforementioned goals, this study partly used a concept proposed by Schellong et al. (2018), based on signalling theory with an assumption that a FB status is a credible signal to consumers. In signalling theory, a sender sends a signal to a recipient in a communication process with asymmetric information (Spence, 1973). The sender decides how to signal information to the receiver, who interprets this signal. Referring to this theory, Issock (2018) argues that trust becomes a vital factor for purchasing when the buyer feels susceptible. In this paper, three elements were added to a simple model used by Wolf (2018): aware and unaware buyers, the means of communication, a tangible brand and trust embracing purchase intention. Wolf's research focuses on FB identity communication in the signalling theory context. The Wolf's B2B approach extends here to B2C markets and a legal construct with a direct message of being a FB addressed to consumers.

In the previous analyses of FB, consumers were not divided into segments of those familiar and unfamiliar with FB, albeit the two groups emerged. Such an approach is applied in this study in line with Brunner's et al. (2019) who uses the signalling theory, exploring brands, purchase intensions, and opposite segments. Moreover, Christidis et al. (2011), Woodside and Summers (2012), Wang et al. (2015), divide buyers into those aware and unaware while investigating awareness of various market offers. Martin and Strong (2016) link two opposite groups with trust, branding, and purchase intention. The enumerated frameworks orient this article towards a search for the potential direct message signalling FB status. Moreover, they proved the necessity of understanding whether this signal might have a potential influence on trust-building accompanied by purchasing behaviour.

Besides the aforementioned research questions, the above line of reasoning motivates us to propose the following hypotheses:

H1: Positive perceptions of FB prevail in both segments.

H2: The potential influence of an endorsed FB identity on purchase intention is stronger among aware than unaware consumers.

To summarize, the reviewed literature noticeably indicates that there exists a dearth of knowledge on the relationships comprising buyers' awareness of FB, signalling FB status, trust, and purchase intentions. The approach adopted in this study is presented on the Figure 1. 
potential in building consumer trust towards FB

accompanied with purchase

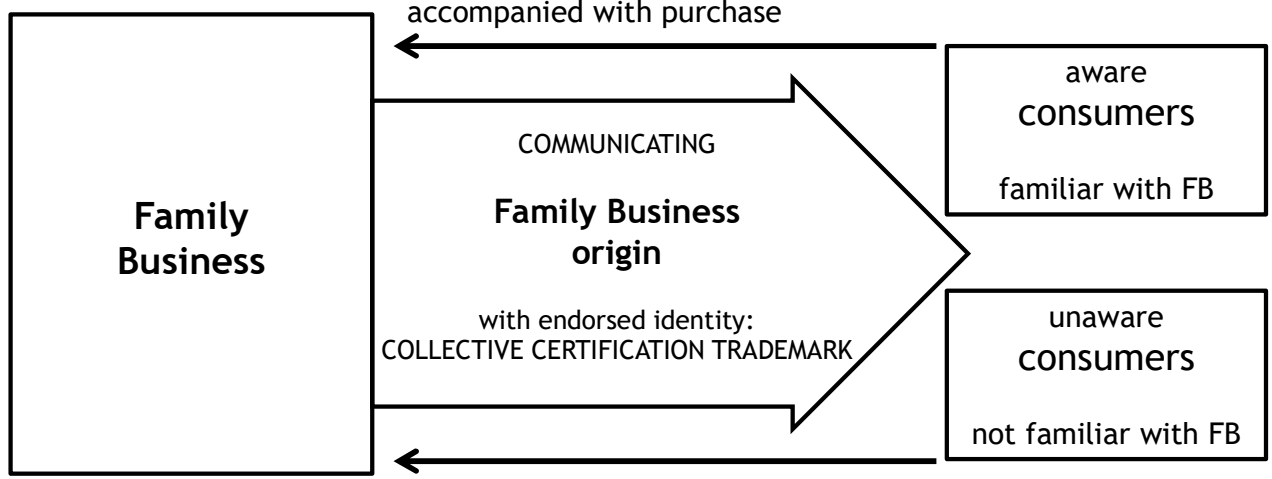

potential in building consumer trust towards FB

accompanied with purchase

Figure 1. Conceptual framework

Source: own elaboration.

\section{MATERIAL AND METHODS}

For the purpose of this study, a nationwide quantitative survey of a unique statistically representative random-cluster sample of 1091 consumers was conducted in January 2018 by using the online survey method. In Poland, it was a 'neutral' shopping period, therefore reducing the impact of environmental influences and ensuring the respondents' accessibility.

\section{Methods and Techniques}

The sample covered Polish active buyers - in traditional shops and those who purchase offline and online - aged 16-60 who shared their shopping experiences with others, who potentially and actually influenced other buyers, and who used the Internet on a regular basis.

Adopting these characteristics of the surveyed population ensued from the article's aims. All these criteria were checked in a filtering question. Before the primary survey, a pilot study was conducted to confirm the research procedure assumptions and comprehensibility of the online questionnaire. It ensured the instrument reliability and validity for complete data collection. This approach was based on the fundamentals of pre-survey qualitative research pursuant to the protocol proposed by Mariampolski (2001), Anninou, Foxall, Saldana, and Omasta (2018) conducted in the second half of 2017. The protocol includes 10 participant observations in 10 shops selected appropriately for the enquiry aims and 20 in-depth interviews with consumers who fulfilled the precise criteria. Describing trust, the respondents used such words as reliability, longevity, business with a human face, high quality products, and commitment towards local communities, which was consistent with prior studies. Thus, later in the survey, trust was replaced by phrases instead of direct investigation. Those stages were vital to prepare, among other things, 14 attributes on the consumers' associations with FB included in the question: "What are your associations with FB?" And on six statements regarding FB included in the question: "To what 
extent do you agree (or disagree) with the following statements on FB in Poland?" In both questions, a five-point Likert scale was applied with opposite answers: from strongly agree to strongly disagree. With support of an external company of high expertise, ABM - Marketing Research Agency from Warsaw, the online questionnaire with three filtering, 11 major, and three personal questions was addressed to eligible respondents. The sample reflected statistics on gender, age, place of living, according to the population marginal distribution in Poland. The respondents also reported their education level, type of household, and assessment of financial status. Descriptive statistics are reported in Table 1.

Table 1. Respondent demographic characteristics

\begin{tabular}{|c|c|c|}
\hline & Demographic attribute & $n=1091$ \\
\hline gender & \begin{tabular}{|l|} 
Female \\
Male
\end{tabular} & $\begin{array}{l}51 \% \\
49 \% \\
\end{array}$ \\
\hline age & \begin{tabular}{|l|}
$16-19$ \\
$20-25$ \\
$26-30$ \\
$31-40$ \\
$41-50$ \\
$51-60$
\end{tabular} & $\begin{array}{l}10 \% \\
15 \% \\
12 \% \\
19 \% \\
23 \% \\
21 \% \\
\end{array}$ \\
\hline type of household & $\begin{array}{l}\text { alone } \\
\text { with a partner but without children } \\
\text { with a partner and with children } \\
\text { with children but without a partner } \\
\text { with other people }\end{array}$ & $\begin{array}{c}8.6 \% \\
31.5 \% \\
29.9 \% \\
6.7 \% \\
23.3 \% \\
\end{array}$ \\
\hline
\end{tabular}

Source: own study.

\section{Data Analyses}

Frequencies, sums, means, and standard deviations were calculated for full data and separately for groups of aware and unaware consumers and for the demographic variables. Statistical significance level was $p=0.05$.

The evaluation of test usability was based on reliability analysis: the degree of consistency with which the test results reflected the analysed feature. In the assessment of the cohesion of scale positions, an integrity analysis was performed using the internal consistency method. All items in the test contain more than two categories of answers on a five-point Likert scale; hence, the Cronbach's alpha coefficient of reliability was determined, as this is the best indicator of reliability for such a test. The higher the index value, the more reliable the scale (see: Jakubowska \& Radzymińska, 2019).

The factor analysis was used to explain the observed relationship between test questions within individual characteristics. First, Bartlett's test of sphericity was used to verify the null hypothesis that the correlation matrix is a unit matrix $(\mathrm{HO}: \mathrm{R}=\mathrm{I})$. Then the KaiserMeyer-Olkin Test was used to verify the usefulness of factor analysis for the evaluation of relations between the observed variables. The significance of eigenvalues was assessed by isolating factors using the Principal Components Analysis method (see Kargol-Wasiluk \& Wildowicz-Giegiel, 2018). This factor extraction method was used to form uncorrelated linear combinations of the observed variables. The number of factors/attributes for further analysis was determined according to the Kaiser criterion (Kaiser, 1960) and the scree 
plot. The Varimax method was used for factor rotation. This method minimised the number of variables that have high loads for each factor, simplifying the interpretation of the factors. Statistical analysis was conducted using IBM SPSS version 25.

Furthermore, according to the literature review (Christidis et al., 2011, Woodside \& Summers, 2012; Wang et al., 2015, Martin \& Strong 2016; Brunner et al., 2019) and the qualitative stage results, the buyers were divided into two segments. The first one covered $11.37 \%$ of the whole sample $-n=124$ buyers familiar with FBs and portraying such firms with proper criteria - while the second one covered $46.84 \%$ of the whole sample: $n=511$ buyers with no knowledge of FBs, which was statistically verified. Other buyers declared that they knew 'something' about FBs but were unable to provide any details, and their ambiguous answers excluded them from the most of analyses.

\section{RESULTS AND DISCUSSION}

The innovative and original idea of this paper was to examine what attributes are assigned to FBs by consumers familiar and unfamiliar with FBs in the context of trust-building accompanied by purchase intentions. Moreover, this study aimed to indicate a means of how communicating family-owned business nature, especially in Poland perceived twofold: as a strong economic leader among transition states (Bogdan et al., 2015) yet with a rather traditional family-oriented society (Trends in consumers' behaviour in Poland, 2017; Zupan et al., 2017).

\section{Attributes Assigned to FBs by Aware and Unaware Consumers in Poland}

Most of the buyers from segment 1 could list at least one name of a Polish FB. On the other hand, an overwhelming number of consumers from segment 2 could not give any examples of an FB (Table 2).

Table 2. Two major consumer segments

\begin{tabular}{|l|l|l|l|}
\hline \multicolumn{2}{|c|}{ Segment 1. Aware consumers } & \multicolumn{2}{c|}{ Segment 2. Unaware consumers } \\
\hline could list at least one name of a Polish FB & $57.26 \%$ & could list at least one name of a Polish FB & $14.48 \%$ \\
\hline did not mention any FB & $42.74 \%$ & did not mention any FB & $85.52 \%$ \\
\hline
\end{tabular}

Source: own study.

In general (in the whole sample of 1091 consumers), the familiarity with Polish FB was stronger among older buyers. Younger consumers aged 20-25 (84.52\%) and 26-30 (81.25\%) did not list any FB compared to $65.09 \%$ of those aged $51-60$.

In order to identify groups of attributes characterising an $\mathrm{FB}$, the following question was posed: "What do you associate with FB?" Fourteen starting attributes were assumed. Surprisingly, despite declaring unfamiliarity with FBs, the unaware buyers were able to ascribe some attributes to FBs. Both segments had explicit associations with FBs based on their prior experiences. Such a phenomenon is explained by Woodside and Summers (2012), who claim, that awareness alone does not cause consumer response.

The results of calculations showed that three eigenvalues exceeded the value of one, according to Kaiser's criterion. As can be seen from Table 3, variables fall into three groups of factors, which can be defined as positive (feature 1, 4, 5, 7, 8, 12, 13 and 14 in the group of aware consumers while $1,4,5,7,12,13$ and 14 in the group of unaware 
consumers), neutral (feature 2, 3 and 6 in the group of aware consumers while 2, 3 and 8 in the group of unaware consumers), and negative (feature: 9, 10 and 11 in the group of aware consumers while 6, 9, 10 and 11 in the group of unaware consumers). Trust for FBs understood as reliability, longevity, business with a human face, high quality products, and commitment towards local communities (Hosmer, 1995; Harris et al., 2003; Hill \& O'Hara, 2006; Castelfranchi \& Falcone, 2010; Hobbs \& Goddard, 2015) was reflected in this study in dominant features ascribed by both segments: reliability, long presence on the market, 'human' approach to the client, high quality products, good for the local community (attributes 1, 4, 12, 13, 14).

Table 3. Rotated factor matrix and indicators that determine the suitability of data to detect the structure of FB attributes

\begin{tabular}{|c|c|c|c|c|c|c|}
\hline \multirow[t]{2}{*}{ FB attributes } & \multicolumn{3}{|c|}{$\begin{array}{c}\text { Aware consumers } \\
n=124\end{array}$} & \multicolumn{3}{|c|}{$\begin{array}{l}\text { Unaware consumers } \\
\qquad \mathrm{n}=511\end{array}$} \\
\hline & positive & negative & neutral & positive & neutral & negative \\
\hline 1. reliability & 0.828 & -0.058 & -0.047 & 0.815 & 0.223 & -0.006 \\
\hline 2. relations, managed by family members & 0.169 & 0.031 & 0.740 & 0.125 & 0.826 & 0.113 \\
\hline 3. passes from generation to generation & 0.533 & -0.158 & 0.545 & 0.432 & 0.775 & 0.006 \\
\hline 4. operates long on the market & 0.704 & 0.081 & 0.340 & 0.565 & 0.266 & 0.094 \\
\hline 5. organic products & 0.755 & -0.016 & -0.253 & 0.779 & -0.012 & 0.097 \\
\hline 6. goods, services a bit more expensive & 0.027 & 0.348 & 0.564 & 0.270 & 0.395 & 0.517 \\
\hline 7. local Polish products & 0.818 & -0.096 & 0.173 & 0.800 & 0.196 & 0.055 \\
\hline 8. tradition & 0.693 & -0.178 & 0.385 & 0.568 & 0.595 & -0.089 \\
\hline $\begin{array}{l}\text { 9. with trouble (incompatibilities in the } \\
\text { family) }\end{array}$ & -0.103 & 0.828 & -0.017 & -0.008 & -0.119 & 0.837 \\
\hline 10. underinvested & 0.007 & 0.837 & -0.018 & 0.088 & -0.088 & 0.800 \\
\hline 11. nepotism (favouring family members) & -0.155 & 0.778 & 0.223 & -0.105 & 0.296 & 0.739 \\
\hline 12. 'human' approach to the client & 0.830 & -0.123 & 0.128 & 0.824 & 0.152 & -0.015 \\
\hline 13. high quality products, workmanship & 0.865 & -0.025 & 0.212 & 0.828 & 0.182 & 0.036 \\
\hline 14. good for the local community & 0.765 & -0.109 & 0.269 & 0.689 & 0.408 & -0.025 \\
\hline$\%$ of cumulative variance, after rotation & 37.66 & 53.49 & 65.69 & 33.47 & 449.79 & 65.50 \\
\hline KMO & & & 0.873 & & & 0.896 \\
\hline \multirow[t]{3}{*}{$\begin{array}{l}\text { Bartlett's test } \\
\text { of sphericity }\end{array}$} & & & 909.358 & & & 3506.794 \\
\hline & & & 91 & & & 91 \\
\hline & & & 0.000 & & & 0.000 \\
\hline
\end{tabular}

Source: own study.

Similarly to prior findings, even the unaware buyers in Poland reacted positively to FBs; according to the Edelman Trust Barometer (2017), only 51\% of consumers know which firms they buy from are FBs, although the level of trust for them is high among the interviewees. Regarding aforementioned FB's longevity, workmanship, and tradition appreciated by buyers, Becut (2011) argues that consumers seek offers sealed with quality marks with strong identity, highlighted either by emphasised valorisation of wellknown products or by the revitalisation of traditional products. Concluding from Table 3 , buyers associated three outstanding positive attributes with FB: product quality, approach to buyers, and reliability. The same attributes were indicated by both segments 
and can create the basis for distinguishing FB from other firms. Therefore, this research contributes to prior studies in which consumer perceptions of the FB are positive (e.g. Orth \& Green, 2009; Binz et al., 2013; Rosina, 2018; Sageder et al., 2018). The local origin of products also played a vital role here.

The buyers were also asked about the extent to which they agree or disagree with statements regarding FBs in Poland (Table 4). For this purpose, six opening sentences were formulated. The calculation scheme was the same as in the previous question. The Cronbach's alpha coefficient of reliability for aware consumers was 0.74 and for unaware consumers -0.72 . While considering these results, a particular attention should be paid to statements 4 and 5 , which directly refer to sending a message to the audience and agree with the signalling theory (Wolf, 2018; Schellong et al., 2018).

Table 4. Rotated factor matrix and indicators determining the suitability of the data to detect the structure of the consumers' statements

\begin{tabular}{|c|c|c|c|c|c|}
\hline \multirow{2}{*}{\multicolumn{2}{|c|}{ Statements }} & \multicolumn{2}{|c|}{$\begin{array}{l}\text { Aware consumers } \\
\qquad n=124\end{array}$} & \multicolumn{2}{|c|}{$\begin{array}{l}\text { Unaware consumers } \\
\qquad \mathrm{n}=511\end{array}$} \\
\hline & & 1 & 2 & 1 & 2 \\
\hline \multicolumn{2}{|c|}{$\begin{array}{l}\text { 1. We need to support FBs, because they are Polish } \\
\text { capital; FBs pay taxes in Poland }\end{array}$} & 0.894 & 0.082 & 0.812 & 0.080 \\
\hline \multicolumn{2}{|c|}{ 2. Poles are unaware of supporting Polish capital } & 0.155 & 0.696 & 0.563 & 0.013 \\
\hline \multicolumn{2}{|c|}{$\begin{array}{l}\text { 3. FBs support each other and strongly cooperate } \\
\text { with each other }\end{array}$} & 0.510 & 0.354 & 0.514 & 0.537 \\
\hline \multicolumn{2}{|c|}{$\begin{array}{l}\text { 4. FBs should promote the fact that they are fam- } \\
\text { ily-owned }\end{array}$} & 0.849 & 0.121 & 0.825 & -0.015 \\
\hline \multicolumn{2}{|c|}{$\begin{array}{l}\text { 5. When shopping, it is worth knowing that a prod- } \\
\text { uct comes from a FB }\end{array}$} & 0.909 & 0.075 & 0.790 & 0.206 \\
\hline \multicolumn{2}{|c|}{$\begin{array}{l}\text { 6. The products offered by FBs are bought by older } \\
\text { consumers }\end{array}$} & 0.033 & 0.836 & -0.068 & 0.926 \\
\hline \multicolumn{2}{|c|}{$\%$ of cumulative variance, after rotation } & 43.85 & 66.12 & 42.49 & 62.42 \\
\hline \multicolumn{2}{|l|}{ KMO } & \multicolumn{2}{|r|}{0.757} & \multicolumn{2}{|r|}{0.771} \\
\hline \multirow[t]{3}{*}{ Bartlett's test of sphericity } & Approx. Chi-Square & & 252.822 & & 726.509 \\
\hline & df & & 15 & & 15 \\
\hline & Sig. & & 0.000 & & 0.000 \\
\hline
\end{tabular}

Source: own study.

The dominant statements (over $80 \%$ of volatility resources) of aware consumers were the need for knowledge that a purchased product came from a FB, the duty of supporting Polish FBs, and expectations of FB status promotion. Factor 2 was dominated by the fact that the products offered by FBs were mainly bought by older people. For unaware consumers, the most important statements were supporting Polish FBs, FBs' promotion, and the origin of products. These reports confirm the high potential for FB in the area of communication with this segment. The unaware consumers unquestionably believed that products offered by FBs were bought by elderly people $(86.30 \%$ of volatility resources). Both segments demonstrated a high level of consumer patriotism, cherishing domestic products by displaying support for Polish FBs and the explicit promotion of FB origin. What is valuable for the entire logic of this study, when compared to buyers from other post-socialist countries, is that Poles are much more ethnocentric 
than Slovenians, Hungarians, Czechs, or Bulgarians, but less than Russians (Han \& Won, 2018). This aspect is worth further investigation.

In general, both segments showed their positive perceptions of FBs, which confirmed the H1: "Positive perceptions of FBs prevailed in both segments."

\section{The Endorsed FB Identity in the Context of Trust-Building Accompanied with Purchase}

The purpose of this study was to detect if a direct message of being a FB addressed to consumers may have the potential to trigger trust-building accompanied with purchase intentions. To respond to this challenge, the consumers were asked about the potential of a clear brand, apparent on FBs' products and activities. It refers to the FB identity endorsed by the collective certification trademark (CCT), a legal construct we presented above.

In the current research, the perceptions of the potential influence of FB brands were ambiguous. In the whole sample of 1091 buyers, $46.10 \%$ of them, notwithstanding demographic variables, declared that FB brands would not have had an influence on their purchase decision (on a five-point verbal intent scale). However, it would have definitely encouraged $15.49 \%$ of buyers and would probably encourage $38.41 \%$ of them, so positive answers prevailed (53.90\%). Such answers agree with Becut's (2011) findings: FB brands could provide a meaning to identity- and value-seekers. This opinion corresponds with Beltramini and Stafford's (1993) conclusion that a brand can be a crucial factor in evaluating a product. Similarly, Morhart et al. (2015) posit that consumer perceptions are based on real evidence judged by provable information, such as labels of origin.

Moreover, tables 5 and 6 present a declared willingness to buy products from Polish FBs, with distinct age and gender groups. Unexpectedly, in the case of unaware buyers, the CCT might attract their attention (41\%). Correspondingly, Woodside and Summers (2012) claim that awareness may not be the essential part of consumer decision-making processes. The familiarity with Polish FBs was stronger among the older buyers, as presented in the above section. However, in the whole sample of 1091 buyers, $20.67 \%$ who 'definitely' approved of FB brands were those aged 31-40. That group was also the most enthusiastic about the brand among unaware buyers. It proves that communicating the FB status may be effective in this segment. Moreover, there may be a chance for the aware buyers to become opinion leaders, as word-of-mouth forms the basis of interpersonal influence and determines the relevance of information (Grewal et al., 2003). It still belongs to the major trustworthy sources of consumer information (Sicilia et al., 2016) having a central role in the formation of consumer attitudes (Herold et al., 2016). Thus, H2 - "The potential influence of an endorsed FB identity on purchase intention is stronger among aware than unaware consumers" - cannot be confirmed as the potential influence of an endorsed FB's identity on purchase is similar in both segments.

Thus, this study contributes to previous research (Beck \& Kenning, 2015; Binz et al. 2013, Craig et al., 2008, Zanon et al. 2019) by suggesting not only that a message of FB origin can be a stimulus for purchase but also presenting a legal construct for the means of such communication. Such a logic was confirmed by Schwass and Glemser (2016) who value the material symbols that express a FB identity.

Prior research robustly proved the positive relation between consumer trust and purchase intention (e.g. Ghai \& Sharma, 2019; Ricci et al., 2018; Issock Issock, 2018; Oliveira et al., 2017). Consequently, in this study, by declaring willingness to purchase and choosing 
FB attributes that constituted trust, the buyers indirectly showed that the endorsed identity had a potential in trust-building. These results are consistent with the deduction that the FB status might appeal to buyers highly involved in the purchasing process, for whom such a brand could lead to enhanced customer trust (Binz \& Botero; 2018).

Table 5. The CCT influence on women's declared purchase decisions

\begin{tabular}{|l|l|l|l|l|l|l|l|}
\hline \multirow{2}{*}{\multicolumn{2}{|c|}{ Purchase }} & \multicolumn{7}{|c|}{ Age } \\
\cline { 3 - 8 } \multicolumn{2}{|c|}{} & $\mathbf{1 6 - 1 9}$ & $\mathbf{2 0 - 2 5}$ & $\mathbf{2 6 - 3 0}$ & $\mathbf{3 1 - 4 0}$ & $\mathbf{4 1 - 5 0}$ & $\mathbf{5 1 - 6 0}$ \\
\hline \multirow{2}{*}{ Aware } & Definitely yes & $0.36 \%$ & $0.18 \%$ & $0.18 \%$ & $0.72 \%$ & $0.54 \%$ & $0.72 \%$ \\
& Rather yes & $0.18 \%$ & $0.36 \%$ & $0.00 \%$ & $0.72 \%$ & $1.61 \%$ & $1.25 \%$ \\
& Rather no & $0.00 \%$ & $0.00 \%$ & $0.18 \%$ & $0.00 \%$ & $0.18 \%$ & $0.00 \%$ \\
\hline \multirow{3}{*}{ Unaware } & Definitely yes & $0.54 \%$ & $0.36 \%$ & $0.54 \%$ & $1.79 \%$ & $1.43 \%$ & $0.54 \%$ \\
& Rather yes & $1.43 \%$ & $3.05 \%$ & $2.33 \%$ & $2.15 \%$ & $3.05 \%$ & $2.51 \%$ \\
& Rather no & $0.18 \%$ & $0.54 \%$ & $0.18 \%$ & $0.90 \%$ & $0.54 \%$ & $0.18 \%$ \\
& Definitely no & $0.00 \%$ & $0.00 \%$ & $0.36 \%$ & $0.18 \%$ & $0.00 \%$ & $0.18 \%$ \\
\hline
\end{tabular}

Source: own study.

Table 6. The CCT influence on men's declared purchase decisions

\begin{tabular}{|l|l|l|l|l|l|l|l|}
\hline \multirow{2}{*}{\multicolumn{2}{|c|}{ Purchase }} & \multicolumn{6}{|c|}{ Age } \\
\cline { 3 - 8 } \multicolumn{2}{|c|}{ Aware } & $\mathbf{1 6 - 1 9}$ & $\mathbf{2 0 - 2 5}$ & $\mathbf{2 6 - 3 0}$ & $\mathbf{3 1 - 4 0}$ & $\mathbf{4 1 - 5 0}$ & $\mathbf{5 1 - 6 0}$ \\
\hline \multirow{2}{*}{ consumers } & Definitely yes & $0,94 \%$ & $0,56 \%$ & $0,19 \%$ & $0,94 \%$ & $0,75 \%$ & $1,69 \%$ \\
& Rather yes & $0,75 \%$ & $0,38 \%$ & $0,56 \%$ & $0,38 \%$ & $1,13 \%$ & $1,31 \%$ \\
& Rather no & $0,56 \%$ & $0,38 \%$ & $0,38 \%$ & $0,56 \%$ & $0,56 \%$ & $0,56 \%$ \\
\hline \multirow{3}{*}{ Unaware } & Definitely yes & $0.38 \%$ & $0.75 \%$ & $0.19 \%$ & $1.69 \%$ & $0.38 \%$ & $0.19 \%$ \\
consumers & Rather yes & $2.25 \%$ & $2.63 \%$ & $1.69 \%$ & $4.32 \%$ & $4.13 \%$ & $1.69 \%$ \\
& Rather no & $0.38 \%$ & $0.38 \%$ & $0.38 \%$ & $0.19 \%$ & $0.56 \%$ & $0.75 \%$ \\
& Definitely no & $0.00 \%$ & $0.19 \%$ & $0.19 \%$ & $0.38 \%$ & $0.38 \%$ & $0.19 \%$ \\
\hline
\end{tabular}

Source: own study.

However, the perceived credibility of a brand issuer constituted a significant factor in deciding whether the brand would be used in decision-making (Kamins \& Marks, 1991; Norberg, 2000). Despite noteworthy studies on third-party certification related to consumer willingness to purchase (Darnall et al., 2018), the crucial issue that surfaced in our research was the choice of a certifier: an organisation conferring a brand and whether the entity would be approved by buyers. Grabber and Lai claim (2011) that the choice of certifier needs bottom-top approach, instead of GOV initiatives and the idea that the effectiveness of endorsed identity depends on relevant marketing and buyer education. Such a solution corresponds to the Polish consumers' mindset.

\section{CONCLUSIONS}

As we indicated in the above empirical study, Polish FBs can benefit from attributes that have a strong potential in trust-building accompanied with purchase intentions. Thus, the findings provide important insights that deepen the understanding of buyers' purchasing behaviour towards a FBs' offer from a post-socialist market perspective. 
Contrary to prior studies on FBs, we presented a new approach that considers the concept of an endorsed identity, and we investigated the endorsed identity's potential. All this contributes to the literature, dividing buyers into aware and unaware segments and presenting their perceptions of FBs separately. Unpredictably, both groups equally supported explicit signalling of FBs' origin and ascribed positive attributes to FBs, particularly those associated with trust. Although such perceptions prevailed, a low level of the buyers' knowledge of FBs reveals a serious challenge in educating the audience. Occasionally, buyers are misguided, as some Polish non-FBs try to take advantage of these virtues, purporting to be kin-owned enterprises. Furthermore, our findings demonstrate consumers' patriotism, proving that the FB identity may additionally benefit from a clear signal of Polish origin. In this context, Poles are closer to Russian buyers but distant to the less ethnocentric Slovenian or Hungarian buyers. In most of these states bottom-top initiatives are better perceived than GOV ones. Thus, this fact should be taken into consideration when choosing a certifier of the CCT. Although the potential influence of the CCT was ambiguous for some sub-segments presented in this study, the CCT might trigger purchase decisions. In that respect the choice of a proper certifier becomes of highest importance.

Concerning limitations of this study, the current findings are based on declarative answers. Instead, future research may use a market experiment conducted in natural purchase setting with products labelled with the examined trademark. Nonetheless, a large sample survey was the most relevant in the exploration of a new field. However, more advanced econometrics could be applied to verify additional hypotheses. It is worth further examination what criteria should be fulfilled by a prospective certifier responsible for conferring the brand. Moreover, extended and detailed studies on the most promising subgroups from profiled segments would help to shape proper communication activities. When focusing on promotional activities, one particular area that future research could examine is how certifications can lead to affinity marketing. Third-party endorsement - in this case the use of third-party certification - is a major distinguishing feature of affinity marketing. It can leverage group affiliation to capitalize on a pre-established relationship that may add persuasiveness and credibility to the sales message. Consumer affinity is positively associated with product trust, which in turn promotes consumer intention to buy products from the group to which the affinity is directed (Guo et al., 2018). Therefore, this study may open new avenues for research on various factors that create a relationship between FBs and buyers, thus influencing purchase decisions.

\section{REFERENCES}

Anninou, I., \& Foxall, G.R. (2017). Consumer decision-making for functional foods: Insights from a qualitative study. Journal of Consumer Marketing, 34(7), 552-565.

Bartlett, M.S. (1937). Properties of Sufficiency and Statistical Tests. Proceedings of the Royal Society of London. Series A, Mathematical and Physical Sciences, 160(901), 268-282. https://doi.org/10.1098/rspa.1937.0109

Beck, S., \& Kenning, P. (2015). The influence of retailers' family firm image on new product acceptance: an empirical investigation in the German FMCG market. International Journal of Retail \& Distribution Management, 43(12), 1126-1143. https://doi.org/10.1108/IJRDM-06-2014-0079

Beck, S. (2016). Brand management research in family firms. Journal of Family Business Management, 6(3), 225-250. https://doi.org/10.1108/JFBM-02-2016-0002 
Beck, S., \& Prügl, R. (2018). Family firm reputation and humanization: Consumers and the trust advantage of family firms under different conditions of brand familiarity. Family Business Review, 31(4), 460-482. https://doi.org/10.1177/0894486518792692

Becut, A. (2011). Apples, Quality Marks and Trademarks for Local Products. International Review of Social Research, 1(2), 65-83. https://doi.org/10.1515/irsr-2011-0011

Bednarz, J., Bieliński, T., Nikodemska-Wołowik, A.M., \& Otukoya, A. (2017). Sources of the competitive advantage of family enterprises: An international approach focusing on China, Nigeria and Poland. Entrepreneurial Business and Economics Review, 5(2), 123-142. https://doi.org/10.15678/EBER.2017.050207

Beltramini, R.F., \& Stafford, E.R. (1993). Comprehension and Perceived Believability of Seals of Approval Information in Advertising. Journal of Advertising, 22(3), 3-13. https://doi.org/10.1080/00913367.1993.10673407

Bhati, S.S. (2015). Relation Between Trust Theory and Agency Theory. In S. Natarajan, M. Ganesh Babu, B. Nagarjuna, \& R. Rajkumar (Eds.), Commerce and Management-A Modern Perspective (p. 451-460). India: Archers and Elevators Publishing House.

Bilan Y., Mishchuk H., Pylypchuk R. (2017). Towards sustainable economic development via social entrepreneurship. Journal of Security \& Sustainability Issues, 6(4), 691-702. http://doi.org/10.9770/jssi.2017.6.4(13)

Bilan, Y., Mishchuk, H., Samoliuk, N., \& Grishnova, O. (2019). ICT and Economic Growth: Links and Possibilities of Engaging. Intellectual Economics, 13(1). https://doi.org/10.13165/IE-19-13-1-07

Binz Astrachan, C., Patel, V.K., \& Wanzenried, G. (2014). A comparative study of CB-SEM and PLSSEM for theory development in family firm research. Journal of Family Business Strategy, 5(1), 116-128. https://doi.org/10.1016/j.jfbs.2013.12.002

Binz Astrachan, C., \& Botero, I.C. (2018). We are a family firm: An exploration of the motives for communicating the family business brand. Journal of Family Business Management, 8(1), 221. https://doi.org/10.1108/JFBM-01-2017-0002

Binz, C., Hair, J.F., Pieper, T.M., \& Baldauf, A. (2013). Exploring the effect of distinct family firm reputation on consumers' preferences. Journal of Family Business Strategy, 4(1), 3-11. https://doi.org/10.1016/j.jfbs.2012.12.004

Blombäck, A., \& Ramírez-Pasillas, M. (2012). Exploring the logics of corporate brand identity formation. Corporate Communications: An International Journal, 17(1), 7-28. https://doi.org/10.1108/13563281211196335

Bogdan, W., Boniecki, D., Labaye, E., Marciniak T., \& Nowacki, M. (2015). Poland 2025: Europe's new growth engine. Warsaw: Mc Kinsey \& Company.

Botero, I.C., Thomas, J., Graves, C., \& Fediuk, T.A. (2013). Understanding multiple family firm identities: An exploration of the communicated identity in official websites. Journal of Family Business Strategy, 4(1), 12-21. https://doi.org/10.1016/j.jfbs.2012.11.004

Botero I.C., Spitzley D., Lude M., \& PrügI R. (2019). Exploring the Role of Family Firm Identity and Market Focus on the Heterogeneity of Family Business Branding Strategies. In E. Memili, C. Dibrell (Eds.), The Palgrave Handbook of Heterogeneity among Family Firms (pp. 909-932). Cham: Palgrave Macmillan.

Botos, S., Szilágyi, R., Felföldi, J., \& Tóth, M. (2020). Readiness for ICT based B2C information flow case study of the hungarian food sector. Agris on-Line Papers in Economics and Informatics, 12(2), 41-51. https://doi.org/10.7160/aol.2020.120204

Bozic, B. (2017). Consumer trust repair: A critical literature review. European Management Journal, 35(4), 538-547. https://doi.org/10.1016/j.emj.2017.02.007 
Brunner, C.B., Ullrich, S., \& De Oliveira, M.J. (2019). The most optimal way to deal with negative consumer review: Can positive brand and customer responses rebuild product purchase intentions?. Internet Research, 29(1), 104-122. https://doi.org/10.1108/IntR-08-2017-0307

Brunet-Tornton, R. (2017). Foreword to the special edition, the return to Europe: a generation of reinventing national identities. Baltic Journal of Management, 12(1), 2-5. https://doi.org/10.1108/BJM-10-2016-0239

Burrell, K. (Ed.). (2016). Polish Migration to the UK in the 'New' European Union: After 2004. London, New York: Routledge.

Carrigan, M., \& Buckley, J. (2008). What's so special about family business? An exploratory study of UK and Irish consumer experiences of family businesses. International Journal of Consumer Studies, 32(6), 656-666. https://doi.org/10.1111/j.1470-6431.2008.00696.x

Castelfranchi, C., \& Falcone, R. (2010). Trust Theory. A Socio-Cognitive and Computational Model. West Sussex, UK: John Wiley \& Sons.

Christidis, N., Tsoulfa, G., Varagunam, M., \& Babatzimopoulou, M. (2011). A cross sectional study of consumer awareness of functional foods in Thessaloniki, Greece. Nutrition \& Food Science, 41(3), 165-174. https://doi.org/10.1108/00346651111132439

Craig, J.B., Dibrell, C., \& Davis, P.S. (2008). Leveraging family-based brand identity to enhance firm competitiveness and performance in family businesses. Journal of Small Business Management, 46(3), 351-371. https://doi.org/10.1111/j.1540-627X.2008.00248.x

Cruz, C.C., Gomez-Mejia, L.R., \& Becerra, M. (2010). Perceptions of benevolence and the design of agency contracts: CEO-TMT relationships in family firms. Academy of Management Journal, 53(1), 69-89. https://doi.org/10.5465/amj.2010.48036975

Dąbrowska A. (2011). Consumer behaviour in the market of catering services in selected countries of Central-Eastern Europe. British Food Journal, 113(1), 96-108. https://doi.org/10.1108/00070701111097367

Darnall, N., Hyunjung J., \& Vazquez-Brust, D. (2018). Third-Party Certification, Sponsorship, and Consumers' Ecolabel Use. Journal of Business Ethics, 150, 953-969. https://doi.org/10.1007/s10551-016-3138-2

de Wenden, C.W. (2016). The Impact of the Economic Crisis on Migration Flows: Polish Immigrants in the UK and Ireland. In: D. Leal, N. Rodríguez (Eds.), Migration in an Era of Restriction and Recession. Immigrants and Minorities, Politics and Policy (pp. 291-304). Cham: Springer. https://doi.org/10.1007/978-3-319-24445-7_15

Dutta, S., \& Pullig, C. (2011). Effectiveness of corporate responses to brand crisis: the role of crisis type and response strategies. Journal of Business Research, 64(12), 1281-1287. https://doi.org/10.1016/j.jbusres.2011.01.013

Eddleston, K.A., Chrisman, J.J., Steier, L.P., \& Chua, J.H. (2010). Governance and Trust in Family Firms: An Introduction. Entrepreneurship Theory and Practice 34(6), 1043-1056. https://doi.org/10.1111/j.1540-6520.2010.00412.x

Edelman Trust Barometer (2017). Special Report: Family Business. Retrieved from https://www.edelman.com/research/family-business-trust on November 22, 2018.

European Commission (2009). Final report of the expert group overview of family-enterprise-relevant issues: Research, networks, policy measures and existing studies. Brussels: Directorate-General for Enterprise and Industry.

Ghai, S., \& Sharma, A. (2019). Effect of Perceived Health Benefits and Trust on Customer's Satisfaction \& Willingness to Pay for Organic Foods. Indian Journal of Community Health, 31(1), 123-126. 
Grewal, R., Cline, T., \& Davies, A. (2003). Early-entrant advantage, word-of-mouth communication, brand similarity, and the consumer decision-making process. Journal of Consumer Psychology, 13(3), 187-197. https://doi.org/10.1207/S15327663JCP1303_01

Guo, G., Tu, H., \& Cheng, B. (2018). Interactive effect of consumer affinity and consumer ethnocentrism on product trust and willingness-to-buy: a moderated-mediation model. Journal of Consumer Marketing, 35(7), 688-697. https://doi.org/10.1108/JCM-06-2017-2239

Hall, C., \& Astrachan, J. (2015). Study: Customers Really Do Trust Family Businesses More. Harvard Business Review Digital Articles, April 27. Retrieved from https://hbr.org/2015/04/study-customers-really-do-trust-family-businesses-more on January 3, 2019.

Han, C.M., \& Won, S.B. (2018). Cross-country differences in consumer cosmopolitanism and ethnocentrism: A multilevel analysis with 21 countries. Journal of Consumer Behaviour, 17(1), e52e66. https://doi.org/10.1002/cb.1675

Hartnett, N., Romaniuk, J., \& Kennedy, R. (2016). Comparing direct and indirect branding in advertising. Australasian Marketing Journal, 24(1), 20-28. https://doi.org/10.1016/j.ausmj.2015.12.002

Harris, L., O'Malley, L., \& Patterson, M. (2003). Professional interaction: exploring the concept of attraction. Marketing Theory, 3(1), 9-36. https://doi.org/10.1177/1470593103003001002

Herold, K., Tarkiainen, A., \& Sundqvist, S. (2016). How the source of word-of-mouth influences information processing in the formation of brand attitudes. Journal of Marketing for Higher Education, 26(1), 64-85. https://doi.org/10.1080/08841241.2016.1146387

Hill, C.A., \& O'Hara, E.A. (2006). A Cognitive Theory of Trust. Washington University Law Review, 84(7), 1723-1724.

Hobbs, J.E., \& Goddard, E. (2015). Consumers and Trust. Food Policy, 52(C), 71-74. https://doi.org/10.1016/j.foodpol.2014.10.017

Hosmer, L.T. (1995). Trust: the connecting link between organizational theory and philosophical ethics. The Academy of Management Review, 20(2), 379-403. https://doi.org/10.2307/258851

Issock Issock, P.B., Mpinganjira, M., \& Roberts-Lombard, M. (2018). Drivers of consumer attention to mandatory energy-efficiency labels affixed to home appliances: An emerging market perspective. Journal of Cleaner Production, 204, 672-684. https://doi.org/10.1016/j.jclepro.2018.08.299

Jakubowska, D., \& Radzymińska, M. (2019). Health and environmental attitudes and values in food choices: a comparative study for Poland and Czech Republic. Oeconomia Copernicana, 10(3), 433-452. https://doi.org/10.24136/oc.2019.021.

Janšto, E., Polakovič, P., Hennyeyová, K., \& Slováková, I. (2019). Analysis of the current support of Emarketing activities in selected enterprises of the wine sector in slovakia. Agris on-Line Papers in Economics and Informatics, 11(4), 31-34. https://doi.org/10.7160/aol.2019.110403

Kaiser, H.F. (1960). The application of electronic computers to factor analysis. Educational and Psychological Measurement, 20, 141-151. https://doi.org/10.1177/001316446002000116

Kamins, M.A., \& Marks, L.J. (1991). The perception of kosher as a third party certification claim in advertising for familiar and unfamiliar brands. Journal of the Academy of Marketing Science, 19(3), 177-185. https://doi.org/10.1007/BF02726494

Kargol-Wasiluk, A., \& Wildowicz-Giegiel, A. (2018). The quality of public finance in the light of fiscal governance concept: implications for the European Union countries. Equilibrium. Quarterly Journal of Economics and Economic Policy, 13(3), 411-426. https://doi.org/10.24136/eq.2018.020

Kim, R.B., \& Chao, Y. (2019). Effects of brand experience, brand image and brand trust on brand building process: The case of Chinese millennial generation consumers. Journal of International Studies, 12(3), 9-21. https://doi.org/10.14254/2071- 8330.2019/12-3/1 
Košičiarová, I., Kádeková, Z., Holotová, M., Kubicová, L., \& Predanocyová, K. (2020). Consumer preferences in the content of loyalty to the yoghurt brand. Agris on-Line Papers in Economics and Informatics, 12(1), 37-48. https://doi.org/10.7160/aol.2020.120104

Lude, M., \& Prügl, R. (2018). Why the family business brand matters: Brand authenticity and the family firm trust inference. Journal of Business Research, 89, 121-134. https://doi.org/10.1016/j.jbusres.2018.03.040

Lušňáková, Z., Juríčková, Z., Šajbidorová, M., \& Lenčéšová, S. (2019). Succession as a sustainability factor of family business in Slovakia. Equilibrium. Quarterly Journal of Economics and Economic Policy, 14(3), 503-520. https://doi.org/10.24136/eq.2019.024

Ma, J., \& Orgun, M.A. (2006). Trust Management and Trust Theory Revision. IEEE Transactions On Systems, Man, And Cybernetics - Part A: Systems And Humans, 36(3), 451. https://doi.org/10.1109/TSMCA.2006.871628

Mariampolski, H. (2001). Qualitative market research: A comprehensive guide. Thousand Oaks - London - New Delhi: Sage Publications.

Mayo, E., \& Fielder, A. (2006). I will if you will. Consumer Policy Review, 16(4), 148-155.

Micelotta, E.R., \& Raynard, M. (2011). Concealing or revealing the family? Corporate brand identity strategies in family firms. Family Business Review, 24(3), 197-216. https://doi.org/10.1177/0894486511407321

Morhart, F., Malar, L., Guevremont, A., Girardin, F., \& Grohmanmn B. (2014). Brand authenticity: An integrative framework and measurement scale. Journal of Consumer Psychology, 25(2), 200218. https://doi.org/10.1016/j.jcps.2014.11.006

Neesham, C., \& Tache, I. (2010). Is there an East-European social model?. International Journal of Social Economics, 37(5), 344-360. https://doi.org/10.1108/03068291011038936

Ners, D. (2017), Coalitional Games, Excessive Competition and a Lack of Trust: An Experimental Approach. Economics and Sociology, 10(2), 227-238. https://doi.org/10.14254/2071789X.2017/10-2/17

Nikodemska-Wolowik, A.M. (2006). Family enterprises - a chance to create a strong Polish business identity. The Marketing Review, 6(4), 301-316.

Norberg, H.M. (2000). Use of Collective Trademarks in Consumers' Choice of Foods - Preliminary Results. Økonomisk Fiskeriforskning, 10(2). Retrieved from https://nofima.no/filearchive/Use\%20of\%20collective\%20trademarks\%20in\%20Consumers\%20Choice\%20of\%20Foods\%20-\%20Preliminary\%20results.pdf on November 15, 2018.

Oliveira, T., Alhinho, M., Rita P., \& Dhillon, G. (2017). Modelling and testing consumer trust dimensions in e-commerce. Computers in Human Behavior, 71(6), 153-164. https://doi.org/10.1016/j.chb.2017.01.050

Orth, U.R., \& Green, M.T. (2009). Consumer loyalty to family versus non-family business: The roles of store image, trust and satisfaction. Journal of Retailing and Consumer Services, 16, 248-259. https://doi.org/10.1016/j.jretconser.2008.12.002

Regulation (EU) 2017/1001 of the European Parliament and of the Council of 14 June 2017 on the European Union Trade Mark. Retrieved from https//: eur-lex.europa.eu/legal-content/EN/TXT/?qid=1506417891296\&uri=CELEX:32017R1001 on November 6, 2018.

Ricci, E.C., Banterle, A., \& Stranieri, S. (2018). Trust to Go Green: An Exploration of Consumer Intentions for Eco-friendly Convenience Food. Ecological Economics, 148(6), 54-65. https://doi.org/10.1016/j.ecolecon.2018.02.010 
Rosina, M. (2018). The Power of Communicating the family Firm Status. The Positive Effect of Family Firms as a Brand on Consumer Buying Behavior and Consumer Happiness. Wiesbaden: Springer Fachmedien.

Roudposhti, V.M., Nilashi, M., Mardani, A., Streimikiene, D., Samad, S., \& Ibrahim, O. (2018). A new model for customer purchase intention in e-commerce recommendation agents. Journal of International Studies, 11(4), 237-253. https://doi.org/10.14254/2071-8330.2018/11-4/17

Saldana, J., \& Omasta, M. (2018). Qualitative research: Analyzing life. Thousand Oaks - London New Delhi: Sage Publications.

Sageder, M., Mitter, C., \& Feldbauer-Durstmüller, B. (2018). Image and reputation of family firms: A systematic literature review of the state of research. Review of Managerial Science, 12, 335377. https://doi.org/10.1007/s11846-016-0216-x

Schellong, M., Kraiczy, N.D., Malär, L., \& Hack, A. (2019). Family Firm Brands, Perceptions of Doing Good, and Consumer Happiness. Entrepreneurship: Theory and Practice, 43(5), 921-946. https://doi.org/10.1177/1042258717754202

Schwass, J., \& Glemser, A.C. (2016). Toolbox-A Process for Moving from Family Identity to Family Business Brand. In: Wise Family Business. London: Palgrave Macmillan.

Sicilia, M., Delgado-Ballester, E., \& Palazon, M. (2016). The need to belong and self-disclosure in positive word-of-mouth behaviours: The moderating effect of self-brand connection. Journal of Consumer Behaviour, 15, 60-71. https://doi.org/10.1002/cb.1533

Skvarciany, V., Jurevičienè, D., Iljins, J., \& Gaile-Sarkane, E. (2018). Factors influencing a bank's competitive ability: the case of Lithuania and Latvia. Oeconomia Copernicana, 9(1), 7-28. https://doi.org/10.24136/oc.2018.001.

Spence, M. (1973). Job market signaling. The Quarterly Journal of Economics, 87(3), 355-374. https://doi.org/10.2307/1882010

Trends in consumers' behaviour in Poland. (2017). In A. Warzybok (Ed.) Polish Society for Market and Opinion Research. Warsaw: AMPS Agencja Marketingowa.

Urbancová, H., \& Hudáková, H. (2017). Benefits of Employer Brand and the Supporting Trends. Economics and Sociology, 10(4), 41-50. https//doi.org/10.14254/2071- 789X.2017/10-4/4

Vassilikopoulou, A., Lepetsos, A., \& Siomkos, G. (2018). Crises through the consumer lens: the role of trust, blame and risk. Journal of Consumer Marketing, 35(5), 502-511. https://doi.org/10.1108/JCM-02-2016-1721

Wang, S.-C., Soesilo, P.K., \& Zhang, D. (2015). Impact of Luxury Brand Retailer Co-Branding Strategy on Potential Customers: A Cross-Cultural Study. Journal of International Consumer Marketing, 27(3), 237-252. https://doi.org/10.1080/08961530.2014.970320

Wolf, S. (2018). Signaling Family Firm Identity: Family Firm Identification and its Effects on Job Seekers' Perceptions about a Potential Employer. Wiesbaden: Springer Gabler.

Woodside, F.M., \& Summers, J. (2012). The Impact of Sponsorship Awareness in Low Involvement Settings. Contemporary Management Research, 8(3), 205-228. https://doi.org/10.7903/cmr.11154

Zanon, J., Scholl-Grissemann, U., Kallmuenzer, A., Kleinhansl, N., \& Peters, M. (2019). How promoting a family firm image affects customer perception in the age of social media. Journal of Family Business Strategy 10(1), 28-37. https://doi.org/10.1016/j.jfbs.2019.01.007

Zupan, N., Dziewanowska, K., \& Pearce, A. (2017). Wanting it all: the challenges of managing young talent in transition economies. Baltic Journal of Management, 12(1), 63-85. https://doi.org/10.1108/BJM-02-2016-0054 


\section{Authors}

The contribution share of authors is the following: Anna M. Nikodemska-Wołowik 35\%, Joanna Bednarz 25\%, Dagmara Wach 20\%, Joseph P. Little 10\%, Mark A. Kubik 10\%.

\section{Anna M. Nikodemska-Wołowik}

Associate Professor at the Faculty of Economics, University of Gdansk; focuses on consumer behaviour, qualitative marketing research, intellectual property protection, family enterprises, corporate identity; expert in numerous research projects; authored and co-authored about 100 publications in Poland and abroad.

Correspondence to: University of Gdansk, Faculty of Economics, Armii Krajowej 119/121, 81-824 Sopot, Poland, e-mail: anna.nikodemska-wolowik@ug.edu.pl

ORCID 가 http://orcid.org/0000-0003-3650-5214

\section{Joanna Bednarz}

Associate Professor at the Faculty of Economics, University of Gdansk; head of the Department of International Business; research work focuses on the competitiveness and internationalization of business entities, new trends in consumption, the behaviour of young consumers, brand and product management; the author of several books and scientific articles.

Correspondence to: University of Gdansk, Faculty of Economics, Department of International Business, Armii Krajowej 119/121, 81-824 Sopot, Poland, e-mail: joanna.bednarz@ug.edu.pl ORCID (1) http://orcid.org/0000-0003-4695-0258

\section{Dagmara Wach}

Assistant Professor at the Faculty of Economics at the University of Gdansk, the Division of Electronic Economy; the author of publications on business economics, behavioural economics, transport economics, and information systems.

Correspondence to: University of Gdansk, Faculty of Economics, ul. Armii Krajowej 119/121, Sopot, Poland, e-mail:dagmara.wach@ug.edu.pl

ORCID (1) http://orcid.org/0000-0001-6419-9870

\section{Joseph P. Little}

Associate Professor of Marketing in the Seidman College of Business at Grand Valley State University; research interests include cross-cultural consumer behaviour, sports marketing, international marketing strategy, and e-commerce; select publications include Journal of Global Marketing, Journal of Marketing Theory and Practice, Marketing Management Journal, and in the book Proliferation of the Internet Economy.

Correspondence to: Seidman College of Business, Grand Valley State University, 3106 L. William Seidman Center 50 Front Avenue SW Grand Rapids, MI 49504-6424, USA, e-mail: littlej@gvsu.edu ORCID (ㄴ) http://orcid.org/0000-0001-7315-8931 


\section{Mark A. Kubik}

A Clinical Professor of Marketing at Grand Valley State University, teaching sales and sales management; the faculty advisor to the student Professional Sales Association and sits on the Seidman College of Business Core Curriculum Review and Revision Task Force; prior to his academic career, he worked as a senior finance executive experienced in corporate strategy design, personal production, and portfolio management.

Correspondence to: Seidman College of Business, Grand Valley State University, 3106 L. William Seidman Center 50 Front Avenue SW Grand Rapids, MI 49504-6424, USA, e-mail: kubikma@gvsu.edu

ORCID (1) http://orcid.org/0000-0003-0804-7295

\section{Acknowledgements and Financial Disclosure}

The paper was prepared within the scope of the project funded by the Poland's National Science Centre (Narodowe Centrum Nauki - NCN) No. 2016/21/B/HS4/01600.

\section{Copyright and License}

This article is published under the terms of the Creative Commons Attribution - NoDerivs (CC BY-ND 4.0) License http://creativecommons.org/licenses/by-nd/4.0/ 